\title{
Quality of Croatian inland bathing areas: Reference to the region and European Union
}

\author{
Dominik Galić1, Arijana Cenov², Dražen Lušić1,3*, Marin Glad², Slaven Jozić4, Bruno Cvetkovićs, \\ Daniel Maestro6,7, Nerma Maestro ${ }^{8}$, Diana Mance ${ }^{9}$ Darija Vukić Lušićc 1,2
}

\begin{abstract}
'University of Rijeka, Faculty of Medicine, Department of Environmental Health, Rijeka, Croatia, ${ }^{2}$ Teaching Institute of Public Health of Primorje-Gorski Kotar County, Department of Environmental Health, Rijeka, Croatia, ${ }^{3}$ Center for Advanced Computing and Modeling, University of Rijeka, Rijeka, Croatia, Institute of Oceanography and Fisheries, Split, Croatia, ${ }^{5}$ Andrija Štampar Teaching Institute of Public Health, Zagreb, Croatia, ${ }^{6}$ Institute for Public Health of the Federation of Bosnia and Herzegovina, Department of Environmental Health, Sarajevo, Bosnia and Herzegovina, ${ }^{7}$ University of Sarajevo, Faculty of Health Studies, Sarajevo, Bosnia and Herzegovina, ${ }^{8}$ Institute for Public Health of Canton Sarajevo, Department of Communal Hygiene, Sarajevo, Bosnia and Herzegovina, 'Department of Physics, University of Rijeka, Rijeka, Croatia
\end{abstract}

\section{ABSTRACT}

Introduction: The Republic of Croatia (HR) has significantly invested in monitoring the quality of inland bathing areas during the past 10 years. The aim of this paper was to analyze the results obtained during the 2014-2019 period and to compare them with the Region (non-European Union [EU] countries neighboring Croatia) and EU. Moreover, bathing water quality data at two bathing areas of Zagreb (lakes Jarun and Bundek) were processed in more detail.

Methods: The quality of inland bathing areas in the HR is monitored in five rivers and five lakes in nine Croatian counties; 19 of the 35 monitored sites are located in Zagreb County. Escherichia coli (EC) was determined by EN ISO 9308-3: 1998, while intestinal enterococci (ENT) were defined by EN ISO 7899-2: 2000. Statistical processing of the results was performed using the Microsoft Excel Statistical Package (Redmond, USA) and Statistica 13.5. (Stat.Sof.Inc., Tulsa, USA); the significance level was set to $p<0.05$.

Results: During the study period, the worst Croatian inland water quality was recorded in 2019 (excellent quality for only $25.9 \%$ of the bathing areas), while the best quality was recorded in 2015 (excellent quality in 57.1\%). On average (20142019), the share of bathing areas with excellent quality in Croatia was $46.3 \%$ (i.e., under the EU average of $85.3 \%$ ); with no poor locations (EU average was nearly $2 \%$ ). A significant positive correlation was found between fecal indicators (EC\&ENT) and the amount of precipitation, while a negative correlation with water and air temperature in lakes.

Conclusions: The quality of Croatian inland bathing areas is significantly lower than the European average, while EU water quality is improving. Regarding the countries bordering Croatia, Italy, Slovenia, and Hungary have achieved better results, while Montenegro, Serbia, and Bosnia and Herzegovina are still in the process of developing the monitoring of the bathing water quality.

Keywords: Bathing water directive; Escherichia coli; inland bathing water; intestinal enterococci; public health; recreational water quality

\section{INTRODUCTION}

Swimming at numerous beaches across Europe is one of the favorite activities of European Union (EU) citizens during the summer months, while the quality of the water is one of the essential criteria for choosing a destination (1-4).

Pollution of recreational waters by fecal wastewaters has been ubiquitous in the past, exposing bathers to increased health risks. For these reasons, the monitoring of bathing water quality in Europe began more than four decades ago.

*Corresponding author: Dražen Lušić, University of Rijeka, Faculty of Medicine, Department of Environmental Health, Braće Branchetta 20, 51000,Rijeka, Croatia. E-mail: drazen.lusic@medri.uniri.hr

Submitted: 23 October 2020/Accepted: 23 January 2021

DOI: https://doi.org/10.17532/jhsci.2021.1110
The publication of the 1975 EU Bathing Water Directive (EEC 76/160) constitutes the relevant legal basis (5). This Directive's content was revised in 2006 (EZ 2006/7/ EZ) (6), in line with scientific and technological progress. Although Croatia has a long tradition of monitoring the quality of marine bathing areas, which have been systematically tested since 1989 , monitoring the quality of inland waters is a relatively new program, implemented since 2011. Initially, only four locations (in the cities of Karlovac and Orahovica) were tested. The following year, Zagreb, Slavonski Brod, and Petrinja were added to the program, and the number of locations grew to 27 . In the subsequent seasons, many other cities and counties were added. The regulation prescribes monitoring of inland water quality in Croatia on bathing water quality (OG 51/14) (7). The 
said regulation specifies the classification of bathing waters of surface waters, water management, and informing the public about the quality of bathing waters (7), with the primary aim of preserving human health and environmental quality protection. According to this regulation, bathing water quality is assessed based on the concentration of two microbiological indicators, Escherichia coli (EC), and intestinal enterococci. Prescribed microbiological indicators are globally accepted as indicators of fecal contamination. The detection of pathogens in water is very complex, both due to the complexity of the detection methods and challenging sampling and the very low concentrations in which pathogens are present in the environment. At present, EC and intestinal enterococci are considered the most accurate and specific fecal indicator bacteria (FIB = Fecal Indicator Bacteria) (8).

These bacteria reach coastal waters through wastewater discharge (in the event of wastewater drainage system disruptions or septic tank outflow), rain, melting snow, or other precipitation types. While EC is considered a better indicator for assessing the risk of infectious diseases in inland aquatic systems (9), intestinal enterococci are considered a more effective indicator of fecal marine pollution (10) due to greater tolerance to high salinity and more prolonged survival compared to EC $(11,12)$.

According to Directive 2006/7/EC (6), at least 16 datasets need to be collected for a final assessment of bathing water quality, while there is a requirement for sampling during four successive bathing seasons. Based on the examined microbiological indicators' values, water is classified into one of four categories: Excellent, good, sufficient, and deficient. In cases of less than required data, no final estimate is made. This is the case when new sampling locations are defined (due to too short time of data collection), closing off specific areas due to the occurrence of pollution or changes at a particular site that may affect water quality.

The aim of this paper was to document the quality of Croatian inland bathing areas in the 6-year period from 2014 to 2019. The quality of bathing water in Zagreb's bathing areas (Jarun and Bundek), which constitutes most Croatian inland sampling points, was analyzed in more detail. The correlation of hydrometeorological indicators (air temperature, water temperature, and precipitation) with EC and intestinal enterococci concentrations was examined for these lakes. Moreover, a review of the quality of inland bathing waters in EU countries, the 6-year trend of results, and the Croatian ranking in this context are provided.

\section{METHODS}

\section{Study period and sampling sites}

The research covers a 6-year period, from 2014 to 2019. The inland water quality testing program comprised 35 locations in nine Croatian counties. The largest number of testing points was placed in Zagreb County, where water quality is controlled in lakes Jarun (16 locations) and Bundek (3 locations) (Figure 1). Remained locations were located in SplitDalmatia County (four locations), Brod-Posavina County, Osijek-Baranja County and Virovitica-Podravina County (three locations each), Karlovac County, Sisak-Moslavina County, Primorje-Gorski Kotar County, and Lika-Senj County (1 location each).

\section{Microbiological methods}

The Bathing water quality Regulation (7) prescribes methods for testing bathing water for EC and intestinal enterococci. The official laboratory in Zagreb County uses the "Most Probable Number" (MPN) method (EN ISO 9308-3: 1998) for the determination of EC (13). The diluted sample is inoculated into a microtiter plate containing a dehydrated nutrient medium with 96 wells. The microtiter plate is exposed to a Ultraviolet lamp at a wavelength of $366 \mathrm{~nm}$ after previous incubation lasting $26-72$ hours at $44^{\circ} \mathrm{C} \pm 0.5^{\circ} \mathrm{C}$. The presence of $\mathrm{EC}$ is evidenced by the appearance of blue fluorescence, resulting from the hydrolysis of 4-methylumbelliferyl- $\beta$-D-glucuronide. The results are expressed as the MPN of bacteria per $100 \mathrm{ml}$ of sample. Intestinal enterococci are determined by the EN ISO 7899-2: 2000 method, using the membrane filtration technique (14). The method is based on filtering a specific water volume through a membrane filter, which is then transferred to a solid nutrient selective medium (Slanetz Bartley agar). If an increase in typical colonies on the agar membrane (red, brown, or purple colonies) is observed after incubation (36 $\pm 2^{\circ} \mathrm{C}$ for $44 \pm 4$ hours), a confirmatory test is required. For this purpose, the filter is transferred to Bile Aesculin agar, and after incubation, all colonies that show a yellowish-brown to black color are counted as intestinal enterococci (9).

\section{Statistical analysis}

Descriptive statistics describe the test results: Calculating the total number of measurements, arithmetic mean, relative frequency, and graphical. The normality of data distribution was tested using the Kolmogorov-Smirnov test. Since the testing of bathing water quality did not follow the Gaussian data distribution, non-parametric tests were used for statistical analysis. The Kruskal-Wallis $\mathrm{H}$ test was used to determine the statistically significant difference of the observed microbiological indicators during different years and months. The Mann-Whitney U-test was used to determine the difference between the two Zagreb lakes. Spearman's correlation coefficient was used to evaluate the analyses and define the relationship between hydrometeorological indicators (air temperature, water temperature, and precipitation) and the values of microbiological indicators EC and intestinal enterococci in the bathing waters of lakes Jarun and Bundek, Zagreb. These lakes were the bathing areas with the highest number of tested locations during 20142019. Statistical analysis of the results was performed using the Microsoft Excel Statistical Package (Redmond, United States of America) and Statistica 13.5. Data on precipitation and air temperatures for the studied period were provided by the Croatian Meteorological and Hydrological Service, values measured at the Zagreb - Grič meteorological station.

\section{RESULTS}

\section{Number of locations}

In the period 2014-2018, regular monitoring of bathing water quality in Croatia (HR) was conducted at 
27 bathing areas, while during the past bathing season (2019), the number of locations increased to 35. At the EU level, according to the report of the European Environment Agency for 2019 (15), of 26 member states that monitor the quality of inland waters, Germany, has the largest number of locations $(n=1924)$, followed by France $(\mathrm{n}=1304)$, while Greece $(\mathrm{n}=3)$, and Romania $(\mathrm{n}=1)$, have the smallest number. Finally, with 35 locations, Croatia ranks $16^{\text {th }}$ (Figure 2 ) on the list. The number of locations in the EU increased by 449 (7\%) in 20142019, from 6500 to 6949 .

\section{INLAND BATHING WATER QUALITY IN THE PERIOD 2014-2019 IN CROATIA AND THE EU}

In the period 2014-2019, the average quality of bathing water at EU inland bathing areas was generally higher compared to Croatia (15-20). Nevertheless, no location in Croatia was assessed as poor, while at the EU level, poor sites ranged from 1.6\% (2016) to 2.5\% (2014) (Figure 3A). The share of Croatian locations rated as excellent was $42.9 \%$ (2014); then, for the next 4 years (2015-2018), it ranged between $50 \%$ and $60 \%$, while in the last year of the survey (2019), it fell significantly to $25.9 \%$ (Figure 3B). In EU countries, the share of tested sites rated as excellent varied within a narrow range of $83.3 \%$ (2014) to $86.4 \%$ (2018) over the same period (Figure 3B). In the last year of the survey, the share of sites rated as excellent fell slightly to $85.9 \%$. However, considering the research period at the EU Member State level, an ascending trend is noted. In contrast, a declining trend in the Croatian share of excellent grades was recorded in the same period (Figure 3B).

The 6-year average of locations considered as of excellent quality in Croatia is $46.3 \%$, while the respective standard at the EU Member State level is significantly higher $(85.3 \%)$. According to the criteria of the Directive, the average share of European bathing areas of poor quality is only $2.0 \%$, while in Croatia, no location is assessed as poor (Figure 4).

During the 6-year study period, the largest share of sites classified as of poor quality was recorded in Spain (12.6\%; the average of 30 locations per year), followed by Ireland ( $5.6 \%$; the average of 1 location per year), the Netherlands (3.9\%; the average of 24 locations per year), and France (3.6\%; the average of 45 locations per year). Apart from Croatia, Lithuania, Slovenia, Luxembourg, the UK, Greece, and Bulgaria showed non-poor grades (Figure 5). During the 2019 season, Spain had the largest share of "red" locations $(12.7 \%)$.

Considering the results collected from EU Member States during the 2019 (15) bathing season, and the rated locations only, the country with the best result was Luxembourg, with $100 \%$ bathing sites rated as excellent (Total $\mathrm{N}_{\text {sites }}=12$ ), followed by Austria with $98.8 \%$ (Total $\mathrm{N}_{\text {sites }}=260$ ). Other countries with $\geq 95 \%$ excellent locations included Finland

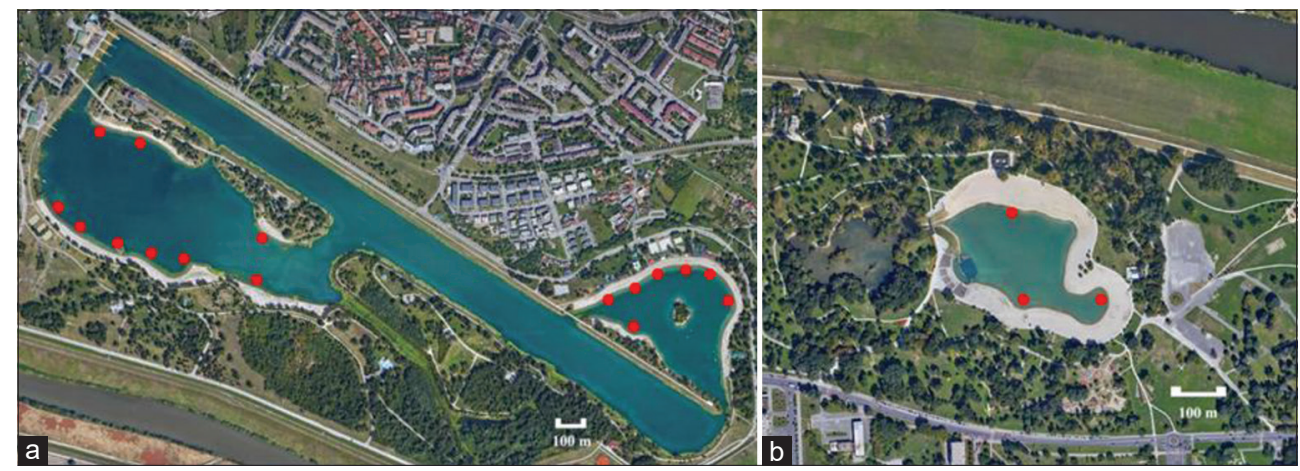

FIGURE 1. Map of lakefront beaches (a) Jarun (b) Bundek. Red points indicate sampling locations.

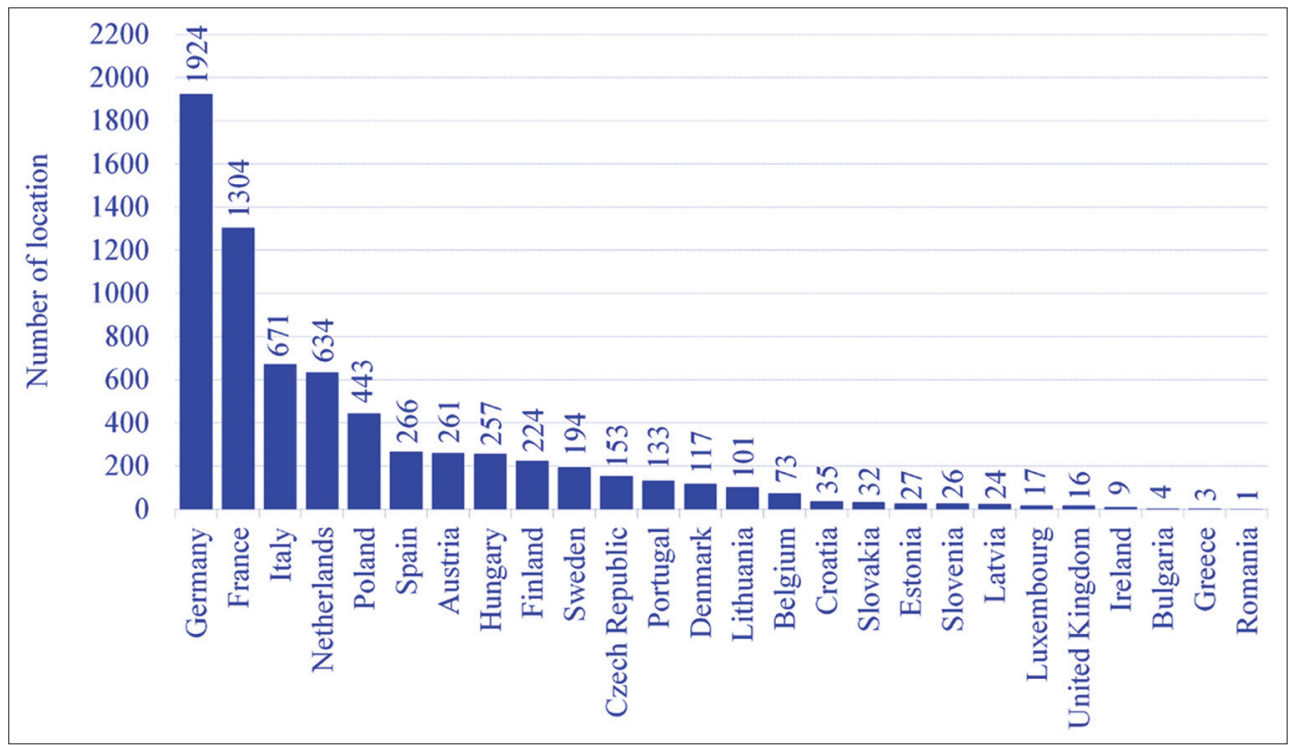

FIGURE 2. Total number of inland bathing waters monitoring sites in European Union member states (2019). 


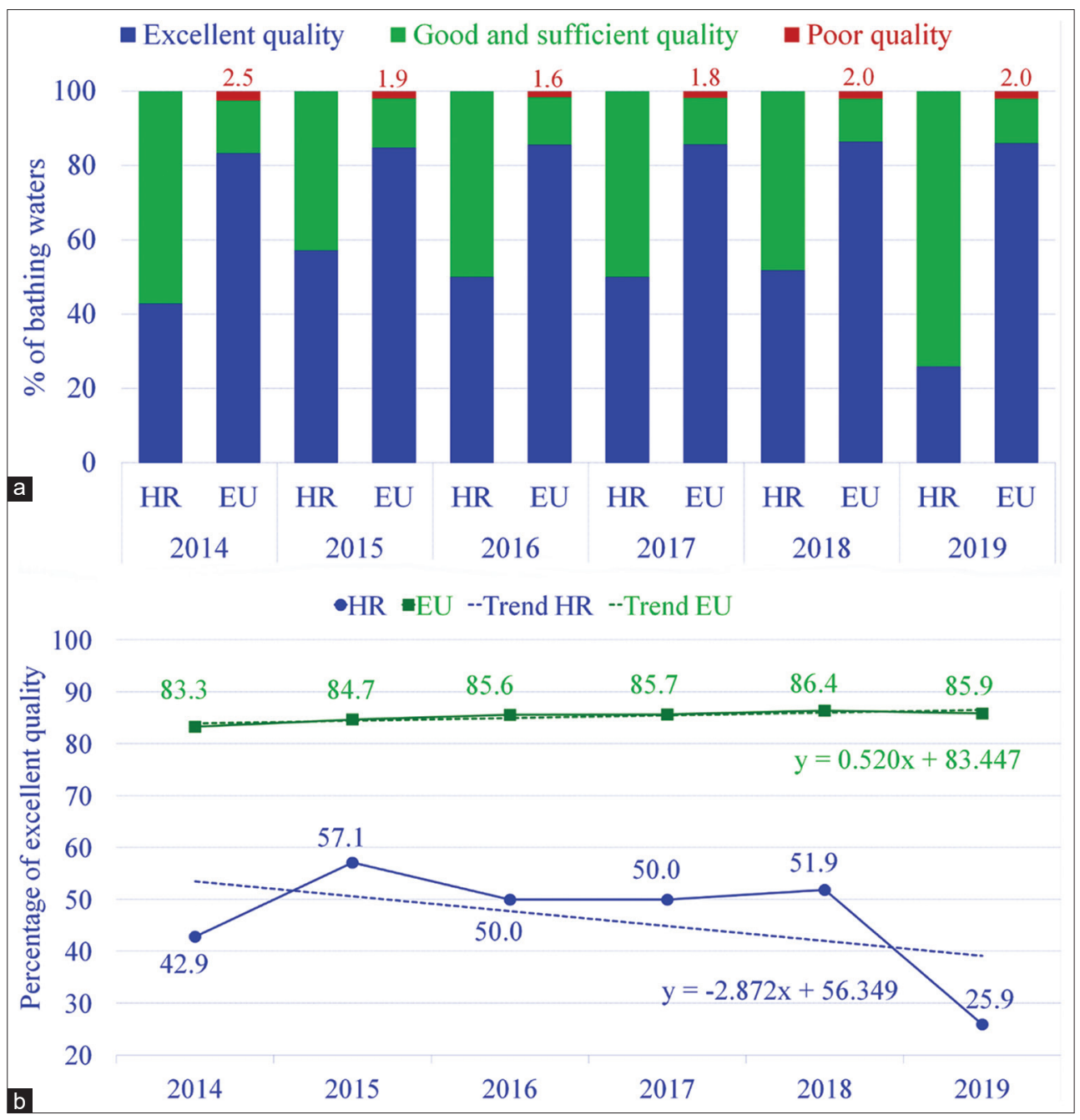

FIGURE 3. (a) Croatian (HR) and European Union (EU) inland bathing water quality, 2014-2019 period (only rated locations are considered); b) The average for $\mathrm{RH}$ and EU bathing sites showing excellent water quality (only rated locations are considered).

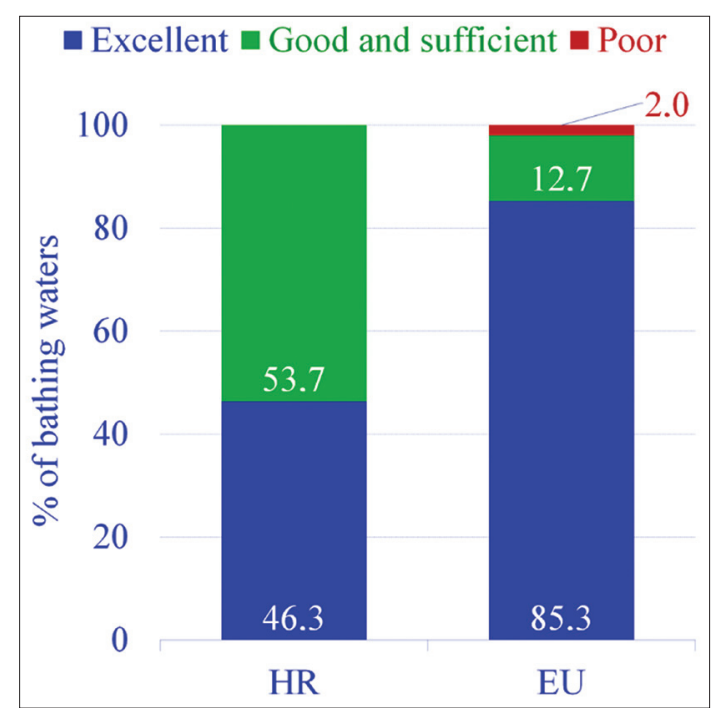

FIGURE 4. 6-year average of Croatian (HR) and European Union inland bathing water quality, 2014-2019 period (only rated locations are considered).

(97.2\%; Total $\left.\mathrm{N}_{\text {sites }}=217\right)$, Denmark $\left(95.7 \%\right.$; Total $\mathrm{N}_{\text {sites }}=$ $115)$, and Germany (95.0\%; Total $\mathrm{N}_{\text {sites }}=1896$ ) (Figure 6). Countries with $<60 \%$ excellent quality sites included Spain (55.2\%; Total $\left.\mathrm{N}_{\text {sites }}=266\right)$, Croatia $\left(25.9 \%\right.$; Total $\mathrm{N}_{\text {sites }}=$ 35), Bulgaria (25.0\%; Total $\left.\mathrm{N}_{\text {sites }}=4\right)$, and Romania ( $0 \%$; $\mathrm{N}_{\text {sites }}=1$ ).

\section{INLAND BATHING WATER QUALITY IN THE 2019 SEASON IN CROATIA AND THE REGION}

During the season of 2019 in Croatia, the share of inland bathing water classified as excellent has halved (compared to 2018), while locations classified as good dominated with $63 \%$ of the share (Figure 7).

Considering the state of the river and lake waters in the countries surrounding Croatia, they can be classified into three groups: (1) EU Member States (Italy, Slovenia, and Hungary), (2) candidates for EU membership (Serbia and Montenegro), and (3) potential candidates for EU membership (Bosnia and Herzegovina). Regarding the EU Member States surrounding Croatia, Italy, had the largest share of locations rated excellent in 2019 (91.7\%). In terms of the total number of locations, Italy is also at the top of the list compared to all EU Member States where bathing water quality is tested (a total of 5535 of which 671 are inland and 4864 sea locations). Hungary follows Italy with $76.8 \%$ (a total of 257 inland locations) and Slovenia (69.2\%, a total of 26 inland locations) in terms of the share of locations rated as excellent, Figure 8. EU candidates and potential candidates (Montenegro, Serbia, and Bosnia and Herzegovina) are still establishing monitoring of inland bathing waters.

According to the latest available data (for the year 2018), the quality of surface water used for recreation in Serbia 


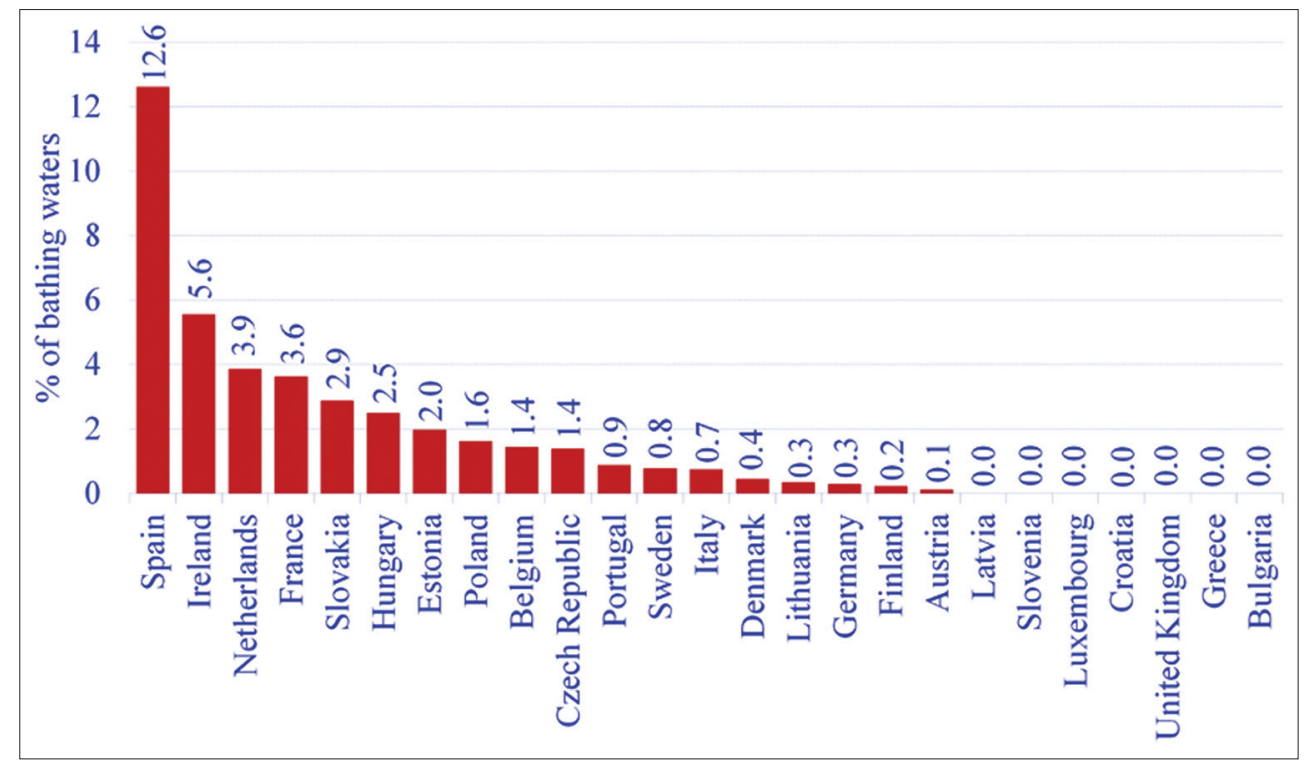

FIGURE 5. 6-year average share of poor-quality European Union inland bathing water sites (2014-2019).

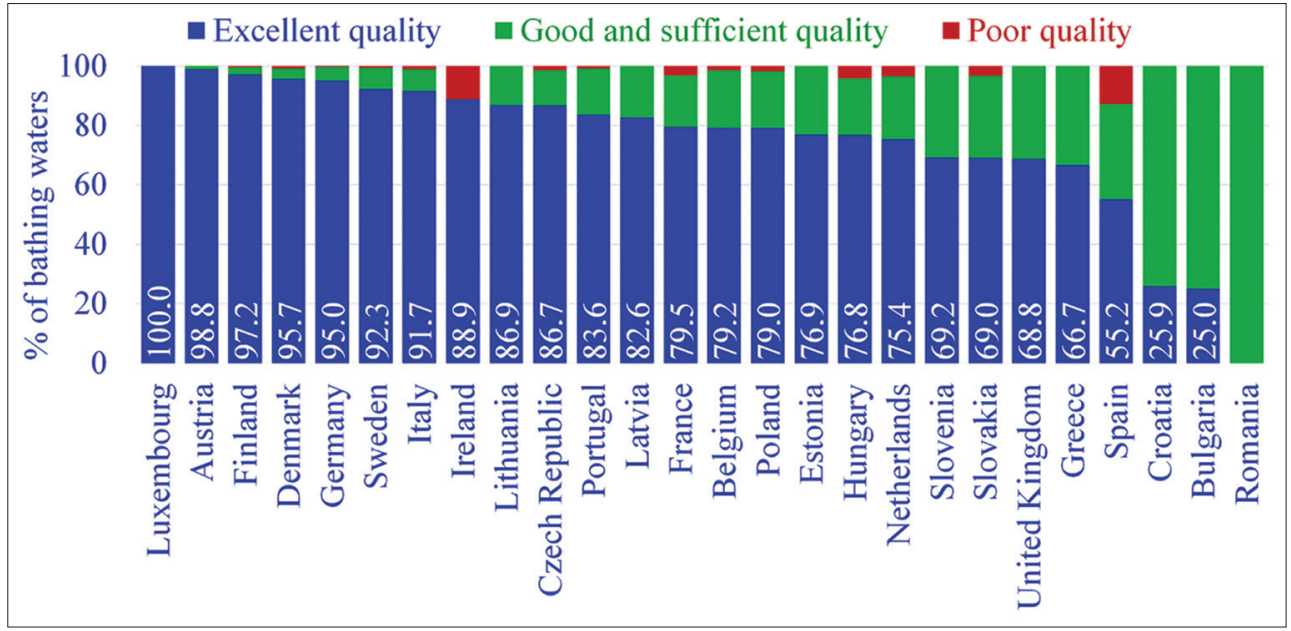

FIGURE 6. European Union quality of inland bathing waters -2019 season.

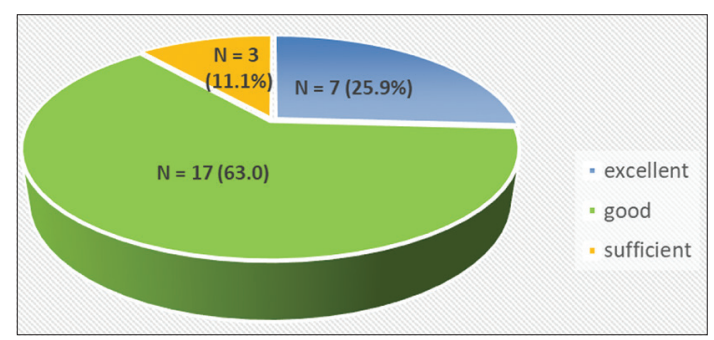

FIGURE 7. Inland bathing water quality in Croatia - 2019 season.

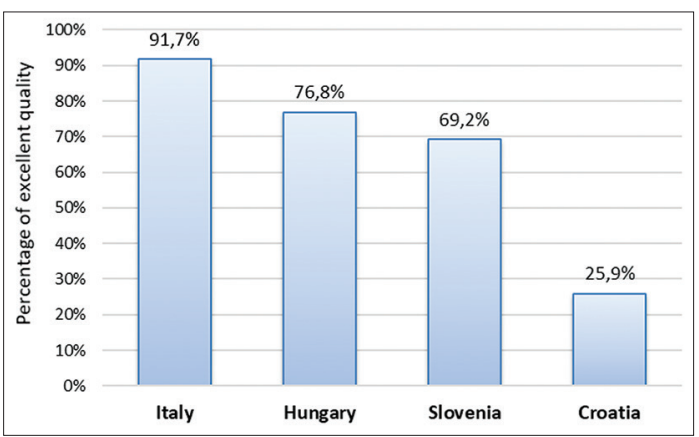

FIGURE 8. The share of bathing areas with excellent quality of inland bathing waters in Croatia and European Union neighboring countries (2019 season). was analyzed at 72 locations, of which 33 in Vojvodina and 39 in Central Serbia. During the same year, 765 water samples were tested for microbiological safety, of which, in accordance with the National criteria (21), 65 (8.5\%) were non-compliant. When compared to the previous year, this represents a decrease of $10 \%$. At a district level, the highest percentage of non-compliant samples $(100 \%)$ was found in the North Banat District. At the same time, the best results were obtained in the South Bačka, Srem, Bor, Jablanica, and Belgrade districts (0\% non-compliant samples) (22).

Regarding Montenegro for the year 2018, the water of 13 rivers (36 measuring points) and three lakes (11 measuring points) used for bathing were analyzed. The testing was carried out in four series of measurements, from April to November, when water pollution was at its highest, as was their use, particularly in terms of recreation (bathing). In that year, $79.7 \%$ of the analyzed lake water samples fell under the required quality class, according to national Regulation (23). On the other hand, for river waters, this percentage was $69.4 \%$ (24).

The inland water quality results for the Federation of Bosnia and Herzegovina $(\mathrm{FBiH})$ were not available. 


\section{Water quality of Zagreb bathing sites - lakes Jarun and Bundek}

Ninteen out of 35 Croatian locations, that is, $54 \%$, are located in Jarun and Bundek, Zagreb's bathing areas. Therefore, the water quality of these bathing areas was analyzed in more detail. The Kruskal-Wallis $\mathrm{H}$ test was used to examine the differences in the values of EC and intestinal enterococci in particular years and months during the study period. As regard the years, year 2019 was the most microbiologically loaded year; enterococcal concentrations were highest in Lake Jarun (median $1.8 \log$ CFU/100 ml, IQR 1.6-2.1; H [5, n = 796] = $114.1, p<0.0001)$ and Bundek $(2.2 \log \mathrm{CFU} / 100 \mathrm{ml}$ IQR 1.6-2.1; H [5, $\mathrm{n}=150]=36.2, p<0.0001$ ) (Figures 9A). In the same year, the highest values of EC were recorded in Lake Bundek (median $2.05 \log$ MPN 100 ml, IQR 1.8-2.3; H [5, $\mathrm{n}=150]=20.5, p=0.001$ ), while in Lake Jarun a peak was measured in year 2014 (median $2.3 \log$ MPN/100 ml, IQR 1.9-2.5; H [5, $\mathrm{n}=796]=144.2, p<0.0001$ ) (Figure 9B).

Considering the months, the highest concentrations of both examined microbiological indicators were measured in September in samples from both the Zagreb lakes. The median enterococcal concentration for Lake Jarun was 2.1 $\log \mathrm{cfu} / 100 \mathrm{ml}, \mathrm{IQR} 1.8-2.3$; $(\mathrm{H}[4, \mathrm{n}=762]=101.6$, $p<0.0001)$ and for Lake Bundek $1.9 \mathrm{log} \mathrm{cfu} / 100 \mathrm{ml}$, IQR 1.6-2.4; $(\mathrm{H}[4, \mathrm{n}=103]=20.2, p=0.0005)$ (Figure 10A). The median EC values for both lakes were highest in September; for Lake Jarun the median was $1.9 \log \mathrm{MPN} / 100 \mathrm{ml}$,
IQR 1.5-2.3; $(\mathrm{H}[4, \mathrm{n}=762]=20.3, p=0.0004)$, and for Lake Bundek 2.1 log MPN/100 ml, IQR 1.8-2.7; (H [4, $\mathrm{n}=103]=10.8, \mathrm{p}=0.029$ ) (Figure 10B).

Concentrations of microbiological indicators in lakes Jarun and Bundek were compared. It was observed that the concentration of EC in Lake Bundek (median 1.9 log MPN/100 ml, IQR 1.6-2.2) was statistically significantly higher (Mann-Whitney $\mathrm{U}, \mathrm{Z}=-3.887$; $p<0.0001$ ) when compared to Jarun (median $1.7 \log \mathrm{MPN} / 100 \mathrm{ml}$, IQR 1.3-2.1). No difference was found in enterococcal values. Considering the meteorological conditions, Figure 11 shows that for the observed period 2014-2019, the average monthly air temperature was lowest in May $\left(17.4^{\circ} \mathrm{C}\right)$ and September $\left(18.1^{\circ} \mathrm{C}\right)$ while precipitation was most abundant in September (average monthly precipitation $128.1 \mathrm{~mm}$ ).

A significant negative correlation between the number of $\mathrm{EC}$ and air temperature ( $\mathrm{rs}=-0.1, p<0.05)$ and water temperature ( $r s=-0.2, p<0.05$ ) was determined by means of Spearman's correlation coefficient. Moreover, a significant negative correlation was found between the concentration of intestinal enterococci and water temperature ( $\mathrm{rs}=-0.1$, $p<0.05)$. The amount of precipitation on the day of sampling was significantly positively correlated with EC ( $\mathrm{rs}=0.1, p<0.05)$. Both microbiological indicators, EC ( $\mathrm{rs}=0.2, p<0.05)$, and intestinal enterococci ( $\mathrm{rs}=0.3$, $p<0.05)$ showed the strongest positive correlation for the 3-day precipitation amount (Table 1).

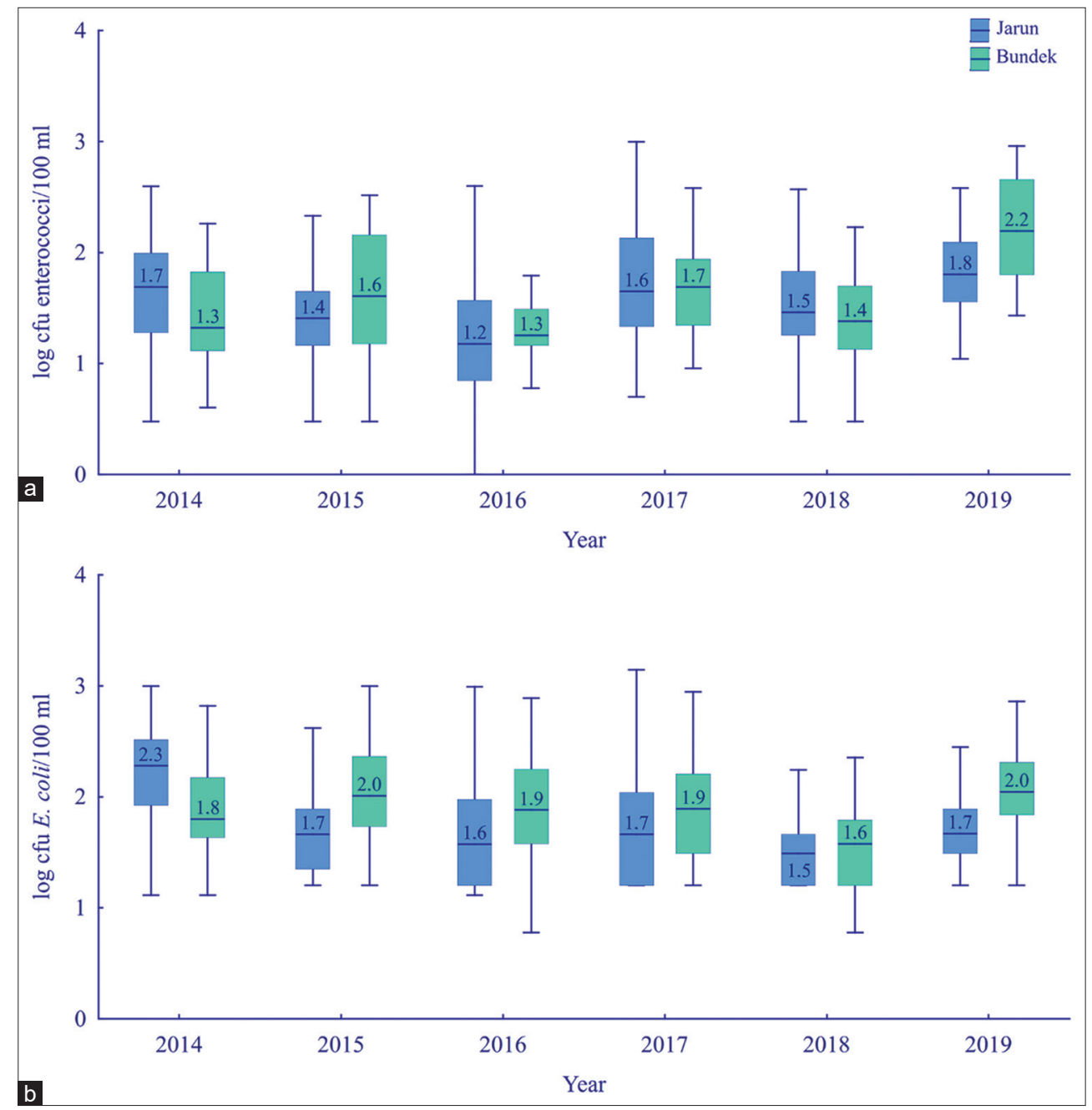

FIGURE 9. Median values of fecal bacteria indicators per year (a) enterococci at Jarun and Bundek beaches and (b) Escherichia coli at Jarun and Bundek beaches. 


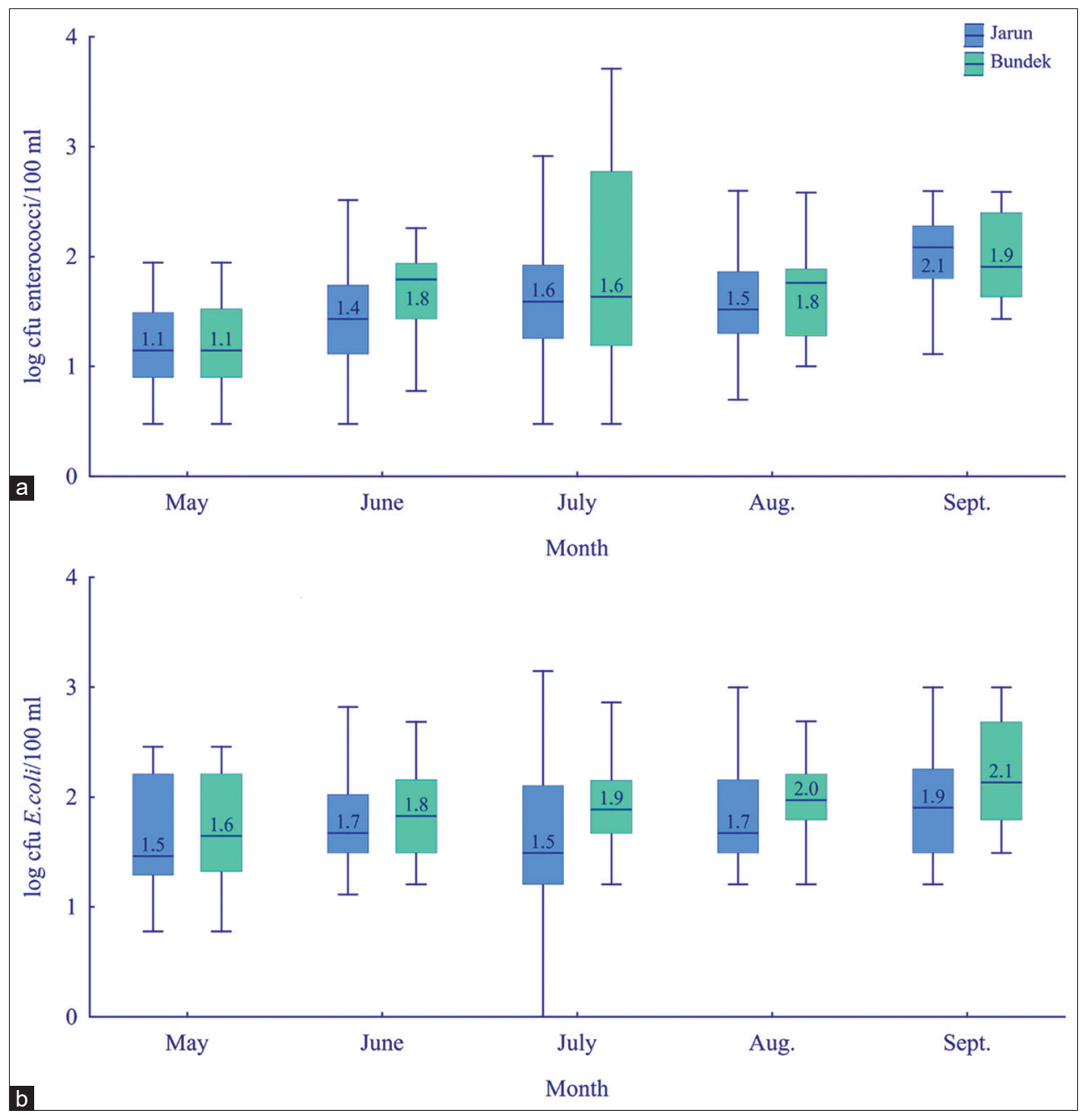

FIGURE 10. Median values of fecal bacteria indicators per month (a) enterococci at Jarun and Bundek beaches and (b) Escherichia coli at Jarun and Bundek beaches.

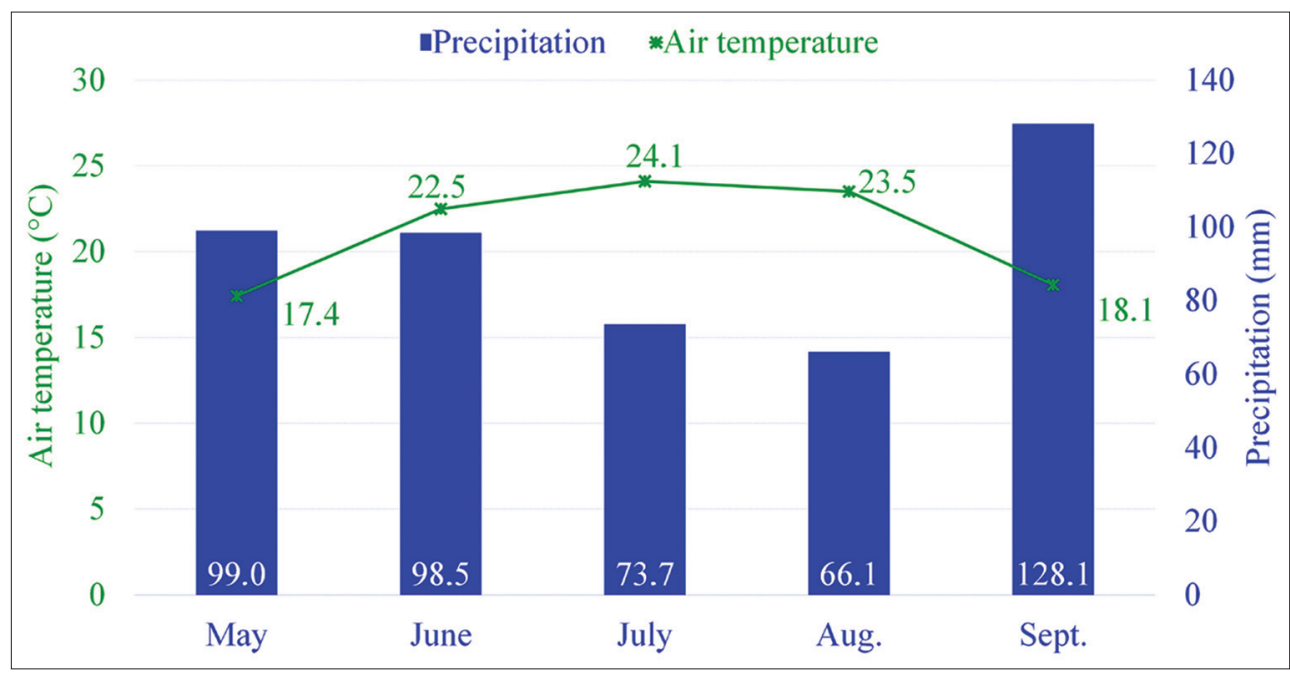

FIGURE 11. Mean monthly temperatures $\left({ }^{\circ} \mathrm{C}\right)$ (dry thermometer) and mean monthly precipitation ( $\mathrm{mm}$ ) at the Zagreb - Grič station for the period $2014-2019$ (Source: Croatian Meteorological and Hydrological Service).

\section{DISCUSSION}

According to the EU report (15), the quality of bathing water during the 2019 season was tested at 22,295 locations, of which one-third were inland bathing areas (rivers and lakes). The number of onshore bathing areas has been continuously increasing at the EU level since 2015, and during 2014-2019 it increased by 449 locations (7\%), from 6500 to 6949 (15). The highest number of new locations subjected to water quality testing are in Poland (by $327 ; 281 \%$ ), Spain (by 30; 13\%), Italy (by $28 ; 4 \%$ ), and Portugal (by 27; 25\%). During the 2014-2019 period, the number of continental bathing sites in Croatia increased by eight locations (30\%), and in the year 2019 amounted to 35 . 
TABLE 1. Spearman's correlation coefficients for the examined variables. Statistically significant correlations are highlighted in bold

\begin{tabular}{|c|c|c|c|c|c|c|}
\hline & $\mathrm{T}_{\mathrm{a}} /{ }^{\circ} \mathrm{C}$ & $\mathrm{T}_{\mathrm{w}} /{ }^{\circ} \mathrm{C}$ & Escherichia coli & Intestinal enterococci & Precipitation (1 day) & Precipitation (3 days) \\
\hline $\mathrm{Ta} /{ }^{\circ} \mathrm{C}$ & - & & & & & \\
\hline $\mathrm{Tw} /{ }^{\circ} \mathrm{C}$ & 0.85 & - & & & & \\
\hline Escherichia coli & -0.14 & -0.15 & - & & & \\
\hline Intestinal enterococci & -0.06 & -0.08 & 0.50 & - & & \\
\hline Precipitation (1 day) & -0.36 & -0.24 & 0.12 & -0.06 & - & \\
\hline Precipitation (3 days) & -0.39 & -0.40 & 0.17 & 0.25 & 0.35 & - \\
\hline
\end{tabular}

$\mathrm{T}_{\mathrm{a}}:$ Air temperature; $\mathrm{T}_{\mathrm{w}}:$ Water temperature

Considering the rated locations only (i.e., excluding "non-classified" locations), the annual percentage of EU bathing areas rated as excellent quality followed an upward trend from 2014 (83.3\%) to 2019 (85.9\%), with the highest share of excellent ratings in the 2018 (86.4\%). During the same period, the largest increase in the share of bathing areas rated excellent was recorded in the UK (28.8\%), Slovenia (26.9\%), and Portugal (22.7\%), while the largest deterioration was recorded in Bulgaria $(75 \%$ decrease in excellent locations) and Croatia (16.9\%). However, the overall improvement in bathing water quality at the EU level over the past 40 years and since the implementation of the EU Bathing Water Directive points to a successful implementation of water policy as well as to the implementation of several different Directives, significant investments in wastewater treatment plants upgrading, and the construction of sewerage networks. Consequently, certain urban bathing areas, where bathing was not possible in the past, are now excellent water quality locations (15).

More than 3\% of poor locations were recorded in Spain, Ireland, the Netherlands, and France (12.6\%, 5.6\%, $3.9 \%$, and $3.6 \%$, respectively). Bathing at microbiologically loaded locations increases the health risks for bathers $(9,25,26)$. The most common disorders are gastroenteritis, followed by febrile respiratory illness (AFRI), ear infections, and skin problems $(26,27)$. At the end of the current year, the bathing area rated poor (annual grade) is closed for bathing for the following season. Test results are not available to the public and that sampling point is excluded from the national report. It is necessary to identify the causes and sources of pollution at such locations and implement measures that will reduce the risk for human health. If a specific site is classified as poor for 5 consecutive years, a permanent ban on bathing is required. For complex and unclear pollution sources, new tools are available, such as Microbial Source Tracking $(28,29)$, which in the past decade has become indispensable for detecting the origin of microbial contamination in various aquatic systems. Genetic markers forming part of certain fecal microbes are closely related to a specific host (e.g., humans, livestock, dogs, and seagulls). They can be used as markers of fecal contamination originating from a particular host.

Among the EU countries in its neighborhood, Croatia achieved the poorest result. The main reason is the low connection of the population to public wastewater drainage systems $(43.6 \%)$. At the same time, Croatian wastewater treatment services cover only $27 \%$ of the population (30). This low connection rate is far below the European average, around $97 \%$ in Western and Central Europe and roughly $70 \%$ in southern, south-eastern, and eastern European countries (31). Ninety-nine wastewater treatment plants have been built in Croatia, but their distribution is not uniform. Most of them are second-stage purification plants, while only eight-third stage plants (32). Looking at particular years, Croatia performed poorest in 2019 and 2014, which can be attributed primarily to the locations of the City of Zagreb (only three out of 19 were rated as excellent in the year 2019). In the 2019 season, only $25.9 \%$ of inland locations rated excellent.

In the Federation of Bosnia and Herzegovina, no bathing criteria have been adopted. Under the EU project "Capacity Building in the Water Sector in $\mathrm{BiH}$," an assessment of the compliance of national bathing water provisions with Directive 2006/7/EC (6) was made. Recommendations for this EU Directive's transposition were made, which are planned to be implemented by subsequent amendments to the Water Act (Official Gazette $\mathrm{N}^{\circ}$ 70/06). At present, the Decree on the classification of waters and waters of the coastal sea of ex-Yugoslavia within the ex-Socialist Republic of Bosnia and Herzegovina is the existing bylaw. It determines the general division of waters into four classes, according to their degree of pollution and purpose, giving the parameters and their limit values for each class (33). This Decree, which is applied as a federal regulation until the bylaw's adoption on the classification of waters in the territory of the Federation of Bosnia and Herzegovina, determines that the II class of water is suitable for bathing. However, this Decree, which serves as the basis for determining recreation and bathing areas, is not harmonized with the effective Water Act. Article 72 of the Water Act (34) prescribes the adoption of a bylaw on the criteria for bathing areas, but these criteria have not been adopted yet. As there is no compliance with Directive 2006/7/EC in the Federation of Bosnia and Herzegovina, and no regulation prescribing such monitoring, the Institute of Public Health of the Federation of Bosnia and Herzegovina, exceptionally, at the request of the Agency for the Adriatic Sea Basin (which is not the case for the Sava River Basin), monitors the quality of surface bathing water at the locations traditionally used for bathing (35). Following the Water Management Strategy of the Federation of Bosnia and Herzegovina 2010-2022, identifying sites suitable for the development of water sports and recreation is foreseen. This strategy also envisages establishing a monitoring and information system for bathing water quality, following Directive 2006/7/EC of the European Parliament and of the Council.

Regarding the two studied lakes in Zagreb, the relationship between hydrometeorological parameters (air temperature, water temperature, and precipitation) and the values of the analyzed microbiological indicators were examined using Spearman's correlation coefficient. A weak but statistically 
significant negative correlation was found between air and water temperature and EC and intestinal enterococci values. The increase in air temperature, and thus water temperature, resulted in a decrease in the concentrations of EC and intestinal enterococci in the waters of Jarun and Bundek lakes. In their study, Whitman et al. (36) also examined the effect of weather conditions on EC concentrations in Lake Michigan. They found that the concentrations of EC in water decreased exponentially with day length and exposure to the sun on sunny days. This was in contrast with rainy days when EC inactivation was reduced. The load of both EC and intestinal enterococci was most significant in September in both studied lakes and was also characterized by the lowest mean air temperature $\left(18.1^{\circ} \mathrm{C}\right)$.

Concerning the changes in the concentration of microbiological indicators per month during the bathing season, a peak is observed for both indicators and both Zagreb lakes in September, the month with the most abundant precipitation $(128.1 \mathrm{~mm})$. The strongest positive correlation was found between the 3-day precipitation value (precipitation amount on the day of sampling and the previous 2 days) and both microbiological indicators. The effect of precipitation on the concentrations of EC at eight beaches of Lake Michigan was studied by Kleinheinz et al. (37). In their study, samples were collected no later than an hour and a half after the meters recorded more than $5 \mathrm{~mm}$ of rain in 24 hours. The study showed that for six of the eight beaches, there was a significant correlation between precipitation amount and elevated concentrations of EC in the studied lake. Laureano-Rosario et al. (38) studied the influence of environmental factors on enterococcal concentrations in the recreational waters in San Juan (Puerto Rico). A significant positive correlation was found between precipitation amount and enterococcal concentrations in the waters, especially after 4 consecutive days of rain. Comparing the water quality of the two studied Zagreb lakes, it can be concluded that the quality is somewhat poorer in Lake Bundek, given that the concentrations of EC are statistically significantly higher compared to Lake Jarun.

The aforementioned results show that there is a lot of room for improving the water quality in inland bathing areas of Croatia. One of the essential preconditions for assessing the real situation is implementing a monitoring program aiming not only at the protection of human health but also at the preservation of the aquatic environment. Public awareness about the negative effects of polluted recreational waters and bathers and visitors' responsibility should be raised.

\section{CONCLUSION}

The number of Croatian and EU inland locations where bathing water quality is systematically tested is continuously increasing. However, the percentage of Croatian bathing areas rated as excellent is significantly below the EU Member States average. While a growing number of excellent locations are found in the EU, the number is declining in Croatia. Therefore, along with Bulgaria, Croatia is experiencing the steepest decline in the share of excellent ratings. Of the countries neighboring Croatia, Italy has the largest share of locations rated excellent.
It should be noted that Italy has the largest number of beaches (inland and coastal). Nevertheless, Croatia has the poorest performance of all direct EU neighbors (Italy, Slovenia, and Hungary). Montenegro, Serbia, and Bosnia and Herzegovina are still developing their monitoring of inland bathing areas, with no legal obligation to report the European Commission results.

At Zagreb's bathing sites, Jarun and Bundek, EC, and enterococci's values were significantly negatively correlated with air and water temperature. A positive correlation was found with the amount of precipitation, and in particular cumulative precipitation, 3-days before sampling. The end of the bathing season (i.e., September), which is characterized by lower air temperature and the highest amount of precipitation, is associated with Zagreb's beaches with the highest microbiological contamination highest recorded in Lake Bundek. The year 2019 was the worst season of the 6-year study period.

\section{COMPETING INTERESTS}

The authors declare that they have no competing interests.

\section{FUNDING}

The University of Rijeka partially supported this work as part of the two research projects: "Adaptation to the new EU Bathing Water Directive" (project code: uniri-biomed-18-292) and "Karst modeling with public and socio-economic implications" (project code: Uniri-prprirod 19-24).

\section{ACKNOWLEDGMENTS}

The authors would like to thank the Department of Environmental Protection and Health Ecology staff, Andrija Štampar Teaching Institute of Public Health, for their technical support. Also, the authors would like to acknowledge the Croatian Meteorological and Hydrological Service for providing meteorological data.

\section{REFERENCES}

1. Dodds R, Holmes M. Education and certification for beach management: Is there a difference between residents vs visitors? Ocean Coast Manag 2018;160:124-32. https://doi.org/10.1016/j.ocecoaman.2018.03.043.

2. Papadopoulou L, Phillips P, Twigger-Ross $C$, Krisht S. The Value of Bathing Waters and the Influence of Bathing Water Quality: Literature Review. Edinburgh: Scottish Government, Social Research Series; 2018.

3. Preißler S. Evaluation of the Quality of European Coastal Water by German Tourists. Coastline Reports; 2009. 177-86. Report No.: 12

4. Slater R, Mearns K. Perceptions and activity profiles of Blue Flag beach users in South Africa. Afr J Hosp Tour Leis 2018;7:1-14.

5. Council Directive of 8 December 1975 Concerning the Quality of Bathing Water (76/160/EEC): Council of the European Union; 1976. https://doi.org/10.1017/cbo9780511610851.053.

6. Directive 2006/7/EC of the European Parliament and of the Council of 15 February 2006 Concerning the Management of Bathing Water Quality and Repealing Directive 76/160/EEC: Council of the European Union; 2006.

7. Official Gazette of the Republic of Croatia "Narodne Novine" N ${ }^{\circ} 51 / 14$. Regulation on Bathing Water Quality: The Government of The Republic of Croatia; 2014.

8. Buer AL, Gyraite $G$, Wegener P, Lange X, Katarzyte M, Hauk G, et al. Long term development of bathing water quality at the German baltic coast: Spatial patterns, problems and model simulations. Mar Pollut Bull 2018;135:1055-66. https://doi.org/10.1016/j.marpolbul.2018.08.048.

9. Marion JW, Lee J, Lemeshow S, Buckley TJ. Association of gastrointestinal illness and recreational water exposure at an inland US beach. Water Res 2010;44(16):4796-804 
https://doi.org/10.1016/j.watres.2010.07.065

10. US Environmental Protection Agency. Recreational Water Quality Criteria. Office of Water. EPA-820-F-12e058. U.S.A.: US Environmental Protection Agency; 2012.

11. He L, He Z. Water quality prediction of marine recreational beaches receiving watershed baseflow and stormwater runoff in Southern California, USA. Water Res 2008:42:2563-73

https://doi.org/10.1016/j.watres.2008.01.002

12. Sagarduy M, Courtois S, Del Campo A, Garmendia JM, Petrau A. Differential decay and prediction of persistence of Enterococcus spp. and Escherichia coli culturable cells and molecular markers in freshwater and seawater environments. Int J Hyg Environ Health 2019;222(4):695-704.

https://doi.org/10.1016/j.jijheh.2019.04.011.

13. International Organization for Standardization. EN ISO 9308-3:1998; Wate Quality-detection and Enumeration of Escherichia coli and Coliform Bacteria in Surface and Waste Water-Part 3: Miniaturized Method (Most Probable Number) by Inoculation in Liquid Medium. London, United Kingdom: International Organization for Standardization; 1998.

https://doi.org/10.3403/02296411u.

14. International Organization for Standardization. EN ISO 7899-2:2000. Water Qualitydetection and Enumeration of Intestinal Enterococci-Part 2: Membrane Filtration Method. London, United Kingdom: International Organization for Standardization: 2000

https://doi.org/10.3403/02036023u.

15. European Environmental Agency. European Bathing Water Quality in 2019. Denmark: European Environmental Agency; 2020.

16. European Environmental Agency. European Bathing Water Quality in 2014. Denmark: European Environmental Agency; 2015.

17. European Environmental Agency. European Bathing Water Quality in 2015. Denmark: European Environmental Agency; 2016.

18. European Environmental Agency. European Bathing Water Quality in 2016. Denmark: European Environmental Agency; 2017.

19. European Environmental Agency. European Bathing Water Quality in 2017. Denmark: European Environmental Agency; 2018.

20. European Environmental Agency. European Bathing Water Quality in 2018. Denmark: European Environmental Agency; 2019.

21. Regulation on Emission Limit Values of Polluting Substances in Surface and Groundwaters and Deadlines for Their Achievement (Official Gazette of the Republic of Serbia 50/2012.): Javna ustanova Službeni glasnik Republike Srpske; 2012.

22. Report on the Hygiene Safety on the Surface Water Captured for Watersuply Used for Recreational Purpose in 2018; Belgrade, Serbia: Institute for Public Health of Serbia "Dr. Milan Jovanovic Batut; 2019

23. Regulation on Surface and Subsurface Waters Classification and Categorization (Official Gazette of Montenegro, №. 2/07): The Government of the Republic of Montenegro; 2007.

24. The State of Water Quality in Montenegro in 2018. Institute of Hydrometeorology and Seismology of Montenegro, Department for Water Quality. Podgorica; 2019.
25. Cui Q, Fang T, Huang Y, Dong P, Wang H. Evaluation of bacterial pathogen diversity, abundance and health risks in urban recreational water by amplicon next-generation sequencing and quantitative PCR. J Environ Sci (China) 2017:57:137-49. https://doi.org/10.1016/j.jes.2016.11.008.

26. Federigi I, Verani M, Donzelli G, Cioni L, Carducci A. The application of quantitative microbial risk assessment to natural recreational waters: A review. Mar Pollut Bull. 2019;144:334-50 https://doi.org/10.1016/j.marpolbul.2019.04.073.

27. World Health Organization. Bathing Water Quality and Human Health: Faecal Pollution. Farnham, UK: World Health Organization; 2001.

28. Ballesté E, Demeter K, Masterson B, Timoneda N, Sala-Comorera L, Meijer WG Implementation and integration of microbial source tracking in a river watershed monitoring plan. Sci Total Environ. 2020;736:139573. https://doi.org/10.1016/j.scitotenv.2020.139573.

29. Frick C, Vierheilig J, Nadiotis-Tsaka T, Ixenmaier S, Linke R, Reischer GH, et al. Elucidating fecal pollution patterns in alluvial water resources by linking standard fecal indicator Bacteria to river connectivity and genetic microbial source tracking. Water Res. 2020;184:116132.

https://doi.org/10.1016/j.watres.2020.116132.

30. Government of the Republic of Croatia. The Implementation Plan for Water Utility Directives. Croatia: Government of the Republic of Croatia; 2010.

31. Ilakovac B. Municipal Wastewater Treatment and the Challenges of the $21^{\text {st }}$ Century. Croatia: Hrvatska Vodoprivreda; 2019. p. 12-4.

32. Molak Milić Z. Municipal Wastewater Treatment Plants in the Republic of Croatia. Croatia: Hrvatska Vodoprivreda; 2017. p. 32-5.

33. Regulation on Classification of Waters and Coastal Waters of Yugoslavia Within the Borders of the Socialist Republic of Bosnia and Herzegovina Official Gazette SR BiH, $N^{\circ}$ 19/80. The Government of the Federation of Bosnia and Herzegovina; 1980.

34. Water Act. Official Gazette of the Federation of Bosnia and Herzegovina N ${ }^{\circ} 70 / 06$ : Parliament of the Federation of $\mathrm{BiH} ; 2006$.

35. Base Analysis of the Situation in Bosnia and Herzegovina to Implement the Protocol on Water and Health to the UN Convention on the Protection and Use of Transboundary Watercourses and International Lakes: Ministry of Foreign Trade and Economic Relations of Bosnia and Herzegovina; 2018.

36. Whitman RL, Nevers MB, Korinek GC, Byappanahalli MN. Solar and temporal effects on Escherichia coli concentration at a Lake Michigan swimming beach. Appl Environ Microbiol. 2004;70(7):4276-85 https://doi.org/10.1128/aem.70.7.4276-4285.2004.

37. Kleinheinz GT, McDermott CM, Hughes S, Brown A. Effects of rainfall on E. coli concentrations at door County, Wisconsin beaches. Int J Microbiol 2009;2009:876050. https://doi.org/10.1155/2009/876050

38. Laureano-Rosario AE, Symonds EM, Rueda-Roa D, Otis D, Muller-Karger FE. Environmental factors correlated with culturable enterococci concentrations in tropica recreational waters: A case study in Escambron Beach, San Juan, Puerto Rico. Int J Environ Res Public Health. 2017;14(12):602 https://doi.org/10.3390/ijerph14121602. 